\title{
ANALISIS IMPLEMENTASI FULL DAY SCHOOL SEBAGAI UPAYAPEMBENTUKAN KARAKTER SISWA DI SD MUHAMMADIYAH 4 KOTA MALANG
}

\author{
Endah Wulandari'), Marhan Taufik' ${ }^{2)}$, Kuncahyono ${ }^{3)}$ \\ 1. SDN Sidomulyo 3 Pacitan \\ 2. Universitas Muhammadiyah Malang \\ 3. Universitas Muhammadiyah Malang \\ Email: wulantyara@yahoo.com,kuncahyono@umm.ac.id
}

\begin{abstract}
Abtsract : Character is very important for students. One effort of qualified students' character building is by religion-based school and implement full day school system that continuously character building can be reached. This study is aimed to know: (1) the implementation of full day school in students' character building in SD Muhammadiyah 4 Malang, (2) constraints in implementing full day schoolin students' character building in SD Muhammadiyah 4 Malang, and (3) solutions on the constraints in implementing full day school system for students' character building in SD Muhammadiyah 4 Malang. This study used qualitative study and type of study conducted was descriptive. As data source or informant is principal, vice principal for curriculum, teachers of II-B and V-B SD Muhammadiyah 4 Malang. Result of this study shows that: (1) The implementation of full day school in SD Muhammdiyah 4 Malang is conducted a day full from 07.00 WIB to 15.30 WIB in order to develop the students' character building process in SD Muhammadiyah 4 Malang is conducted through cultural practice in school such as routine activities, spontaneous activities and character building method. Students character building also developed through extracurriculars. (2) Constraints in implementing full day school in students' character building is students' awareness, the less of support and appreciation from parents or students' custody, and available facilities. (3) solution in solving constraints problem are conducting development to all school members, having connection and cooperation with students' custody; they are by forming association of GPS (Gerakan Peduli Sekolah), maximizing grant, and school facilities.
\end{abstract}

Keywords: implementation, Full Day School, character

\begin{abstract}
Abstrak: Karakter sangat penting bagi siswa. Salah satu upaya untuk membentuk karakter siswa yang berkualitas adalah melalui sekolah yang berbasis agama dan menerapkan sistem full day school agar pembentukan karakter secara kontinu tersebut dapat mencapai hasil. Penelitian ini bertujuan untuk mengetahui: (1) implementasi full day school dalam pembentukan karakter siswa di SD Muhammadiyah 4 Malang, (2) kendala implementasi full day school dalam pembentukan karakter siswa di SD Muhammadiyah 4 Malang, dan (3) Solusi atas kendala implementasi full day school dalam pembentukan karakter siswa di SD Muhammadiyah 4 Malang. Hasil penelitian ini menunjukkan: (1) Pelaksanaan full day school di SD Muhammdiyah 4 Malang dilaksanakan melalui kegiatan pembelajaran sehari penuh mulai pukul 07.00 WIB sampai pukul 15.30 WIB, pembentukan karakter siswa di SD Muhammadiyah 4 Malang dilaksanakan melalui budaya sekolah yaitu kegiatan rutin, kegiatan spontan dan menggunakan metode pembentukan karakter. Pembentukan karakter siswa juga dilaksanakan melalui kegiatan ekstrakurikuler. (2) kendala dalam penerapan full day school dalam pembentukan karakter siswa yaitu kesadaran siswa, kurangnya dukungan dan apresiasi dari beberapa orang tua atau wali murid, dan sarana prasarana yang belum terpenuhi. (3) Solusi dalam mengatasi kendala yaitu melakukan pembinaan kepada semua warga sekolah, menjalin hubungan dan kerjasama dengan wali murid yaitu dengan membentuk paguyupan GPS (Gerakan Peduli Sekolah), memaksimalkan pendanaan, fasilitas dan sarana prasarana sekolah.
\end{abstract}

Kata Kunci: Implementasi, Full Day School, Karakter 


\section{PENDAHULUAN}

Pendidikan merupakan

kebutuhan yang mutlak perlu dimiliki oleh manusia dalam kehidupannya. Manusia membutuhkan pendidikan untuk menghadapi segala bentuk permasalahan dalam kehidupannya. Manusia tidak bisa lepas dari pendidikan karena pada hakikatnya manusia mempunyai potensi-potensi untuk dapat dididik. Menurut Amri (2010:13) "Pendidikan adalah kunci semua kemajuan dan perkembangan yang berkualitas sebab dengan pendidikan manusia dapat mewujudkan semua potensi dirinya baik sebagai pribadi maupun sebagai warga masyarakat". Melalui pendidikan semua orang dapat mengembangkan seluruh potensi yang dimilikinya

Hal ini menjadikan sekolahsekolah dalam tingkat SD, SMP dan SMA bersaing untuk menciptakan sistem pendidikan yang dianggap mampu menjadikan peserta didik dapat maju, berkembang, bersaing dan mampu bertahan hidup dalam era globalisasi. Salah satunya adalah sistem full day school. Menurut Arifin (2012:107) "Pembelajaran dengan sistem full day school mengharuskan sekolah merancang perencanaan pembelajaran dari pagi hingga sore." Jadi dapat disimpulkan bahwa sistem full day school merupakan ciri khas sekolah terpadu yang pelaksanaan proses pembelajaran sehari penuh yaitu pagi hingga sore hari.

SD Muhammadiyah 4 Malang merupakan salah satu sekolah yang menerapkan sistem full day school sehingga pembelajaran dimulai pukul 07.00-15.00 WIB. Selain itu, SD Muhammadiyah 4 Malang. SD Muhammadiyah 4 Malang membagi dua waktu belajar, yaitu senin sampai jumat merupakan pembelajaran full day
, sedangkan sabtu merupakan student's day (peserta didik belajar dirumah) untuk kelas 1 dan 2, sedangkan untuk kelas 3, 4, 5 dan 6 diadakan kegiatan pengembangan diri seperti ekstrakulikuler tapak suci, kegiatan minat dan bakat, dll. Pembelajaran dengan sistem full day school sangat penting bagi pembentukan karakter siswa.

Menurut Arifin (2012:107) menjelaskan bahwa "sistem full day school merupakan ciri khas sekolah terpadu yang pembelajaran dengan sistem full day school mengharuskan sekolah merancang perencanaan pembelajaran dari pagi hingga sore." Sistem pengajaran dalam full day school yang berlangsung selama sehari penuh, mengemas seluruh progam pembelajaran dan kegiatan siswa di sekolah dalam sebuah sistem pendidikan yang bernuansa islam dengan memberikan waktu tambahan untuk siswa mendalami pelajaran keagamaan. Menurut Sulistyaningsih (2008:65) mengatakan bahwa "full day school merupakan model sekolah umum yang memadukan sistem pengajaran agama secara intensif yaitu dengan memberi tambahan waktu khusus untuk pendalaman keagamaan siswa." Sehingga pembelajaran dengan sistem full day school bertujuan untuk mengembangkan potensi, minat, bakat dan kreativitas anak dengan mencakup aspek kognitif, afektif dan psikomotorik melalui kegiatan intrakurikuler dan ekstrakurikuler yang diadakan oleh sekolah

\section{METODE PENELITIAN}

Jenis penelitian yang digunakan dalam penelitian ini adalah penelitian deskriptif yang memberikan gambaran tentang implementasi full day school sebagai upaya pembentukan karakter siswa di SD Muhammadiyah 4 Kota 
Malang. Pendekatan yang digunakan dalam penelitian ini adalah pendekatan kualitatif.

Penelitian ini dilakukan pada kelas II-B dan V-B di SD Muhammadiyah 4 Malang yang beralamatkan di Jalan Sudimoro, No 19, Lowokwaru, Kota Malang Waktu penelitian dilaksanakan pada Semester Genap Tahun Ajaran 2016/2017. Sumber data yaitu sumber dari mana data itu diperoleh.Sumber data terbagi menjadi dua macam yaitu sumber data primer dan sumber data sekunder.

Instrumen yang digunakan peneliti dalam mengumpulkan data yaitu pedoman observasi, pedoman wawancara, dan dokumentasi. Prosedur penelitian meliputi empat tahap yaitu tahap perencanaan, tahap pengumpulan data meliputi observasi, wawancara dan dokumentasi, tahap analisis data dan tahap pelaporan. Sedangkan analisis data menggunakan empat tahap yaitu pengumpulan data, reduksi data, penyajian data dan penarikan kesimpulan.Cara yang dilakukan dalam memperoleh kebenaran penelitian ini yaitu dengan menggunakan trianggulasi metode dan sumber.

\section{HASIL DAN PEMBAHASAN}

SD Muhammadiyah 4 Malang sudah menerapkan sistem pembelajaran full day school sejak tahun 2011. Tujuan penerapan pembelajaran full day school di SD Muhammadiyah 4 Malang tidak hanya mengajarkan materi pelajaran saja akan tetapi memadukan sistem pengajaran agama secara intensif yaitu dengan memberi tambahan waktu khusus untuk pendalaman keagamaan siswa.

\section{Implementasi Full Day School Dalam Pembentukan Karakter Siswa Di SD Muhammadiyah 4 Malang}

Penerapan progam full day school sangat penting bagi pembentukan karakter siswa. Hal ini dikarenakan lamanya waktu siswa di sekolah sehingga memudahkan guru untuk membimbing dan menanamkan nilainilai yang positif didalam pelaksanaannya. Di SD Muhammadiyah 4 Malang penerapan full day school melalui 3 kegiatan yaitu kegiatan pembelajara full day school, kegiatan melalui budaya sekolah dan kegiatan ekstrakurikuler..

\section{a. Kegiatan Pembelajaran Full Day School di SD Muhammadiyah 4 Malang}

Progam full day school dilaksanakan sehari penuh. Hal ini dikarenakan sistem full day school merupakan ciri sekolah terpadu yang proses kegiatan pembelajaranya mengharuskan sekolah merancang perencanaan pembelajaran dari pagi hingga sore. Sulistyaningsih (2008:59) menyatakan bahwa sekolah bertipe full day ini berlangsung hampir sehari penuh lamanya, yakni dari pukul 08.00 pagi hingga 15.00 sore.

Sistem pengajaran dalam full day school yang berlangsung selama sehari penuh, mengemas seluruh progam pembelajaran dan kegiatan siswa di sekolah secara efektif, karena lamanya waktu disekolah menjadikan waktu belajar siswa menajdi efektif. Baharuddin (2009:227) mengatakan bahwa belajar efektif bagi anak itu hanya 3-4 jam dalam sehari (dalam suasana formal) dan 7-8 jam sehari (dalam suasana informal). Hal ini bermaksud menggali potensi siswa secara total, yaitu dengan menitikberatkan pada situasi dan kondisi ketika anak didik dapat mengikuti proses belajar, tapi juga bermain. Waktu dan sistem pembelajaran full day school di SD 
Muhammadiyah 4 Malang diformat dari pukul 07.00-15.30 WIB.

Kegiatan pembelajaran yang dilaksanakan di sekolah denagn sistem full day school tidak serta merta dalam satu minggu terdapat pendidikan formal saja namun siswa diberikan waktu untuk pengembangan diri. Sulistyaningsih (2008:62) mengatakan bahwa di SD full day selain diberikan pendidikan juga diberikan pembinaan anak melalui pengembangan diri. Karena pada sistem full day diberikan waktu tambahan untuk pengembangan diri, maka pada pendidikan formal hanya ada lima hari efektif dan satu hari pengembangan diri.

Di SD Muhammadiyah 4 Malang, kegiatan belajar juga dilakukan di gezebo atau dihalaman yang penting siswa siap menerima pelajaran tanpa paksaan, sehingga penerapan Kegiatan Belajar Mengajar (KBM) di SD Muhammadiyah 4 malang berbeda dengan penerapan yang dilakukan oleh sekolah-sekolah tempo dulu yang belajar harus diam dan duduk dibangku. Hal ini menjadikan siswa di SD Muhammadiyah 4 Malang tidak merasa bosan ketika proses pembelajaran di sekolah, karena proses pembelajaran di SD Muhammadiyah 4 Malang dikemas dengan pembelajaran enjoy full learning.

\section{b. Kegiatan Melalui Budaya Sekolah}

Pada full day school terdapat kegiatan pembentukan karakter melalui budaya sekolah. Kegiatan ini sangat berpengaruh bagi pembentukan karakter siswa. Pembentukan karakter siswa dilaksanakan melalui progam kegiatan rutin, kegiatan spontan dan metode pembentukan karakter. Kegiatan pembentukan karakter ini sejalan dengan pendapat Samani (2012:146) menyatakan bahwa pengembangan budaya sekolah sebagai pembentukan karakter siswa melalui pengembangan diri disarankan melalui empat hal yaitu 1) kegiatan rutin, 2) kegiatan spontan, 3) keteladanan dan 4) pengondisian.

Di SD Muhammadiyah 4 Malang proses pembentukan karakter pada siswa pada pengembangan budaya sekolah dilaksanakan melalui beberapa kegiatan yaitu kegiatan rutin, kegiatan spontan dan menggunakan metode pembentukan karakter. Di SD Muhammadiyah 4 Malang, pembentukan karakter melalui pelaksanaan kegiatan rutin di sekolah dilaksanakan secara teratur, rutin dan dilakukan setiap hari. Adapun kegiatan rutin yang dilaksanakan siswa seperti berdoa sebelum dan sesudah pembelajaran, melaksanakan sholat dhuha, shola berjamaah, salam, salim, membaca Al-Quran, puasa sunah senin kamis, asmaul husna, upacara bendera setiap hari senin, apel pagi yang dilaksanakan pada hari selasa dan rabu dan piket kelas, mengatakan permisi ketika lewat, membersihkan halaman sekolah setiap pagi, menyirami tanaman setiap pagi. Kegiatan pembentukaan karakter siswa di SD Muhammadiyah 4 Malang juga dilaksanakan pada kegiatan spontan. Adapaun kegiatan spontan yang dilakukan siswa di SD Muhammadiyah 4 Malang yaitu mengumpulkan sumbangan untuk korban bencana alam, amal untuk membantu saudara yang membutuhkan, dan mendoakan temannya yang sakit dan mengunjungi teman yang sakit.

Dalam pembentukan karakter pada siswa harus menggunakan metode dalam pelaksanaannya supaya proses pembentukan karakter pada siswa terlaksana dengan optimal. Kegiatankegiatan tersebut dilaksanakan dengan menggunakan kebiasaan-kebiasaan. Daryanto (2013:43) menyatakan bahwa pendidikan karater menekankan pada 
habit atau kebiasaan yang terusmenerus dipraktikkan dan dilakukan.

Dalam implementasiannya, di SD Muhammadiyah 4 Malang guru menggunakan metode keteladanan dan pembiasaan. Peneladanan yang dimaksud yaitu guru di SD Muhammadiyah 4 Malang menjadi model utama untuk melakukan kegiatan seperti sholat, membaca Al-Quran, menyapu, membersihkan toilet, membersihkan halaman sekolah, menyirami tanaman, sehingga siswa juga mencontoh kegiatan yang dilakukan oleh guru. Dengan melakukan pembiasaan maka siswa akan terbiasa dengan kegiatan tersebut dan secara bertahap karakter pada siswa akan tertanam melalui kegiatan yang dilakukan.

\section{c. Kegiatan Ekstrakurikuler}

Pembentukan karakter melalui kegiatan ekstrakurikuler sangat efektif.. Seperti di dalam ekstrakurikuler pramuka hal-hal yang diajarkan adalah nilai-nilai karakter. Hal ini seperti yang dikatakan oleh Samani (2012:147) mengatakan "dalam kegiatan ektrakurikuler apa saja, tergantung kekhasan jenis dan tujuan kegiatan ekstrakurikuler tersebut, selalu ada nilai-nilai karakter yang dikembangkan."

Di SD Muhammadiyah 4 Malang ekstrakurikuler yang wajib adalah pramuka yang diadakan setiap seminggu sekali pada hari Jum'at pukul 13.00 WIB sampai pukul 15.00 WIB yang bertempat di kampus 2, sedangkan ekstrakurikuler tidak wajib adalah tapak suci dan menari. Pada ekstrakurikuler ini siswa memilih sendiri sesuai dengan bakatnya. Sehingga pembentukan karakter siswa juga sangat efektif dilakukan pada kegiatan ekstrakurikuler.

\section{d. Analisis Karakter Siswa SD Muhammadiyah 4 Malang}

Dalam full day school lebih menonjolkan pembelajaran yang religius karena ada jam tambahan untuk pendalaman keagamaan. Sulistyaningsih (2008:65) mengatakan bahwa "full day school merupakan model sekolah umum yang memadukan sistem pengajaran agama secara intensif yaitu dengan memberi tambahan waktu khusus untuk pendalaman keagamaan siswa."

Kegiatan siswa di SD Muhammadiyah 4 Malang yang mengarah kepada karakter religius yeitu kegiatan berdoa sebelum dan sesudah proses pembelajaran, wudhu, sholat dhuha, asmaul husna, sholat dhuhur, sholat sunah sebelum dan sesudah dhuhur, sholat jumat, sholat ashar, sholat tahajud, puasa sunah senin kamis, membaca Al-Quran sebelum membelajaran dan hafalan-hafalan doa, menjadi imam sholat, Qiraati, dan Ummi, infaq dan amal.

Pembentukan karakter yang dibentuk di full day school adalah karakter kemandirian, hal ini dikarenakan siswa di sekolah dengan sistem full day diajarkan untuk bersikap mandiri. Menurut Naim (2012:164) "manusia modern adalah manusia yang mendiri dan tidak tergantung dengan orang lain, dan pentingnya kemandirian harus mulai ditumbuhkembangkan ke dalam diri anak sejak dini." Di SD Muhammadiyah 4 Malang kemandirian siswa terlihat ketika siswa telah sampai di sekolah maka siswa melepas sepatu sendiri dan ditaruh diloker yang telah disiapkan oleh pihak sekolah, siswa mengerjakan tugas yang diberikan oleh guru secara mandiri dan memakan bekal ketika istirahat secara mandiri.

Karakter peduli terhadap lingkungan sekitar juga menjadi titik tekan sekolah dengan sistem full day 
school sebagai pembentukan karakter siswa. seperti yang ungkapkam Naim (2012:200) mengatakan bahwa Manusia berkarakter adalah manusia yang memiliki kepedulian terhadap lingkungan, baik lingkungan sosial maupun lingkungan fisik. SD Muhammadiyah 4 Malang melakukan progam pemeliharaan sejuta pohon. Hal ini dikarenakan SD Muhammadiyah menerapkan progam go green school. Pada progam ini siswa diajak untuk peduli erhadap lingkungan sekitar terutama pohon yang banyak tumbuh di lingkungan sekitar kampus 2.

\section{Kendala Implementasi Full Day}

\section{School Dalam Pembentukan}

Karakter Siswa Di SD

Muhammadiyah 4 Malang

Pada implmentasi full day school dalam pembentukan karakter siswa terdapat beberapa kendala. Kendala itu muncul dari berbagai segi. Terdapat 3 faktor penghambat dalam implementasi full day school dalam pembentukan karakter siswa yaitu sebagai berikut :

\section{a. Kesadaran Siswa}

Kesadaran siswa menjadi hal utama yang sangat penting dalam proses pembentukan karakter bagi siswa tersebut. Di SD Muhammadiyah 4 Malang kendala yang dihadapi dalam pembentukan karakter ini juga berasal dari siswanya sendiri. Siswa yang terkadang tidak mematuhi peraturan sekolah dan tidak mengikuti kegiatan sekolah menjadi kendala bagi sekolah dalam membentuk karakter siswa di sekolah.

Kesuma (2013:78) "Menjadi yang lebih baik sering mempersyaratkan sebuah tindakan nyata dimulai dari kemauan, kemauan membutuhkan kemampuan untuk menolak godaan, teguh menghadapi tekanan dan kemauan adalah inti dari keberanian moral." Sehingga dapat dikatakan bahwa kesadaran diri dari seseorang ialah orang tersebut harus mempunyai kemauan dan tekat yang kuat untuk melakukan sesuatu dimulai dari diri sendiri.

\section{b. Kesadaran Wali Murid}

Orang tua sangat berperan penting dalam menunjang pembentukan karakter siswa. Namun, pada kenyataannya, pelaksanaan full day school untuk membentuk karakter siswa di SD Muhammadiyah 4 Malang kurang mendapatkan dukungan dan apresiasi dari beberapa orang tua atau wali murid. Kegiatan yang dilakukan di sekolah sebagian besar tidak dilakukan di rumah. Hal ini dikarenakan padatnya kegiatan di sekolah full day sehingga orang tua beranggapan jika anak terlalu banyak melakukan kegiatan atau progam sekolah maka waktu untuk istirahat akan berkurang dan bisa berdampat pada sakit.

Peran orang tua sangat penting bagi tumbuhkembang anak, hal ini sejalan dengan pendapat Naim (2012:164) mengatakan bahwa sikap penting yang seharusnya dikembangkan oleh orangtua adalah memberikan kesempatan yang luas untuk anak berkembang dan berproses. Sehingga dukungan dan apresiasi orang tua kepada anak sangatlah diperlukan guna untuk menumbuhkembangkan potensi dan karakter anak menjadi yang lebih baik lagi.

\section{c. Sarana dan Prasarana}

Secara umum berbagai sarana (tempat ruangan) yang berada di sekolah berpotensi untuk melaksanakan kegiatan siswa guna menunjang sistem pembelajaran dan kegiatan yang mengarah ke pembentukan karakter siswa. Menurut Bahauddin (2009:237) mengatakan bahwa sarana dan prasarana merupakan bagian dari pendidikan yang sangat vital guna menunjang keberhasilan pendidikan. Oleh karena itu, perlu adanya pengelolaan pendidikan yang baik, sehingga sekolah dapat dikatakan 
berhasil apabila pengelolaan sarana dan prasarananya juga terpenuhi dengan baik.

\section{Solusi Atas Kendala \\ Implementasi Full Day School \\ Dalam Pembentukan Karakter \\ Siswa Di SD Muhammadiyah 4 \\ Malang \\ SD Muhammadiyah 4 Malang} selalu berupaya melakukan yang terbaik untuk mempersiapkan masa depan peserta didik dan mencetak karakter generasi penerus bangsa melalui kegiatan dalam full day school. Maka upaya yang dilakukan untuk membentuk karakte siswa di SD Muhammadiyah 4 Malang yaitu sebagai berikut:

\section{a. Memaksimalkan Pendanaan dan Sarana Prasarana Sekolah}

Di SD Muhammadiyah 4 Malang terdapat kendala dalam hal kurangnya pendanaan dan sarana prasarana. Untuk mengatasi hambatan tersebut, sekolah berupaya memaksimalkan pendanaan, fasilitas dan sarana prasarana yang ada di sekolah, baik dana dari pemerintah ataupun dana sumbangan pendidikan dari wali murid. Dalam mengoptimalkan kegiatan siswa yang sudah terjadwal tetap berjalan sebagaimana mestinya dengan tujuan membentuk karakter siswa, pihak sekolah berusaha memaksimalkan pendanaan dan fasilitas sarana prasarana di SD Muhammadiyah 4 Malang.

\section{b. Melakukan Pembinaan}

Di SD Muhammadiyah 4 Malang terdapat kendala yairu kurangnya kesadaran anggota sekolah baik siswa maupun guru, maka sekolah terus berupaya melakukan pembinaan. Di SD Muhammadiyah 4 Malang, pembinaan tersebut dilakukan pada semua anggota sekolah baik guru maupun siswa. Dalam pembinaan ini, Kepala Sekolah sangat berperan penting dalam memberikan pengarahan dan pembinaan kepada guru-guru kelas, yang nantinya guru kelas akan menjadi penanggungjawab terhadap kelasnya sendiri-sendiri. Kemudian guru kelas mengaplikasikan ke kelasnya masingmasing dengan melakukan pembiasaan terhadap siswanya. Sehingga kegiatankegiatan yang dilaksanakan guna membentuk karakter siswa akan benarbenar maksimal karena adanya pembinaan dan pembiasaan secara terus menerus.

\section{c. Menjalin Hubungan dan Kerjasama dengan Wali Murid}

Kerjasama antar pihak sekolah dan wali murid sangat menentukan tercapainya tujuan sekolah dalam pembentukan karakter siswa. Keberhasilan pembentukan karakter pada siswa tidak hanya membutuhkan dukungan guru saja namun dukungan dari orang tua sangat dibutuhkan siswa. Adapun langkah di SD Muhammadiyah 4 Malang dalam menjalin hubungan dan kerjasama dengan wali murid ialah dengan membentuk paguyupan GPS (Gerakan Peduli Sekolah).

Hubungan baik antara sekolah dan orang tua sangat penting dalam penunjang keberhasilan tujuan pendidikan, hal ini sejalan dengan pendapat Lickona (2015:561) menyatakan bahwa sekolah harus merekrut orang tua sebagai partner baik tugas khusus maupun mengembangkan nilai moral dan karakter yang baik. Kerjasama antar orang tua dan pihak sekolah berguna untuk mendapatkan imbal balik yang positif bagi pembentukan karakter dan moral siswa.

\section{KESIMPULAN DAN SARAN}

\section{A. Kesimpulan}

Berdasarkan hasil penelitian yang dilakukan oleh peneliti tentang analisis implementasi full day school sebagai upaya pembentukan karakter siswa di SD Muhammadiyah 4 Malang 
maka dapat disimpulkan sebagai berikut:

1. Pelaksanaan full day school sebagai upaya pembentukan karakter siswa di SD Muhammdiyah 4 Malang yaitu kegiatan pembelajaran yang dilaksanakan sehari penuh mulai pukul 07.00 WIB sampai pukul 15.30 WIB yang menggunakan model sekolah dengan pemadatan 5 hari efektif yakni Senin sampai Jum'at, sedangkan untuk hari Sabtu dikhususkan untuk kegiatan pengembangan diri yaitu ekstrakurikuler. Proses pembentukan karakter pada siswa di SD Muhammadiyah 4 Malang dilaksanakan melalui kegiatan budaya sekolah yaitu kegiatan rutin, kegiatan spontan dan menggunakan metode pembentukan karakter. Proses pembentukan karakter siswa juga dilaksanakan melalui kegiatan ekstrakurikuler pramuka dan tapak suci. Nilai karakter pada siswa yang paling menojol di SD Muhammdiyah yaitu karakter religius, mandiri dan peduli lingkungan. Hasil temuan lain di lapangan terdapat karakter lain yang muncul pada siswa di SD Muhammadiyah 4 Malang yaitu karakter disiplin, jujur dan bertanggung jawab.

2. Kendala implementasi full day school dalam pembentukan karakter siswa di SD Muhammadiyah 4 Malang ada tiga faktor yakni kesadaran siswa, kurangnya dukungan dan apresiasi dari beberapa orang tua atau wali murid, dan sarana prasarana dalam menunjang pembentukan karakter siswa belum terpenuhi secara maksimal seperti masjid sebagai sarana ibadah.

3. Solusi sekolah dalam mengatasi kendala implementasi full day school dalam pembentukan karakter siswa di SD Muhammadiyah 4 Malang yaitu sekolah berupaya melakukan pembinaan kepada semua anggota sekolah baik kepada guru maupun siswa,menjalin hubungan dan kerjasama dengan wali murid yaitu dengan membentuk paguyupan GPS (Gerakan Peduli Sekolah) yang terdiri dari wali murid dan memaksimalkan pendanaan, fasilitas dan sarana prasarana sekolah.

\section{B. Saran}

Berdasarkan kesimpulan di atas, peneliti ingin memberikan beberapa saran yang diharapkan dapat dilakukan oleh guru yang terlibat sebagai berikut:

1. Bagi Sekolah

Pada sekolah yang menerapkan sistem full day school, sebaiknya pihak sekolah mengupayakan optimalisasi pada semua aspek. Sekolah perlu mempertimbangkan kesiapan atau ketersediaan sarana dan prasarana yang memadai, memperhatikan kenyamanan anak didik dalam melaksanakan pembelajaran dan kenyamanan orang tua dan masyarakat sekitar dalam menyerahkan kepercayaan sepenuhnya kepada sekolah untuk memaksimalkan seluruh potensi anak didik serta mengaktifkan waktu belajarnya.

2. Bagi Guru

Pada implementasi full day school dalam pembentukan karakter siswa, guru harus selalu menjadi uswatun khasanah, menjadi contoh dan model karakter yang baik serta spiritual yang baik bagi anak didik. Guru harus selalu mengekspor kreativitas dalam menyajikan suatu pembelajaran yang menyenangkan untuk sistem full day school. Selain itu guru bersikap profesional, inovatif dan peka terhadap perkembangan zaman sehingga dapat mencapai keberhasilan dan perkembangan anak yang maksimal.

3. Bagi Siswa

Pada siswa hendaknya mengikuti kegiatan yang telah diprogamkan oleh sekolah dengan sungguh-sungguh dan rajin serta berusaha untuk membantu kelancaran pembentukan karakter agar 
menjadi anak yang memiliki akhlak yang baik dan memiliki pengetahuan yang luas.

4. Bagi Peneliti Selanjutnya

Penelitian ini dapat dijadikan sebagai acuan bagi peneliti selanjutnya mengenai nilai-nilai karakter yang belum muncul pada penelitian sebelumnya di sekolah yang menggunakan sistem full day school.

\section{DAFTAR PUSTAKA}

Ahmadi. 2014. Pengantar Pendidikan Asas \& Filsafat Pendidikan. Yogyakarta: Ar-Ruzz

Amri, Khoiru Ahmadi. 2010. ProsesPembelajaran Kreativ \& Inovatif.Jakarta:Prestasi Pustaka

Annisa, Azizah Nurul. 2014. Program Full Day School Dalam Pengembangan Kemandirian Iswa Kelas IV di SDIT Insan Utama Bantul Tahun Ajaran 2013/2014. Skripsi. UNYJogjakarta, (Online), (eprints.uny.ac.id/14297/1/SK RIPSI_ANNISA\%20N.\%20A. 10108241098.pdf), diakses 5 Desember 2016.

Arifin, Zainal. 2012. Pengembangan Manajemen Mutu Kurikulum Pendidikan Islam. Jogjakara: Diva Press

Arsyadana, Addin (2010), Penerapan Sistem Full Day School Sebagai Upaya Untuk Meningkatkan Kualitas Pendidikan Di Mi Al-Qamar Nganjuk. Skripsi. Malang: UIN Malang, (Online), (etheses.uinmalang.ac.id/4100/1/12140093 .pdf), diakses 5 Desember 2016.

Baharuddin. 2010. Pendidikan dan Psikologi Perkembangan. Jogjakarta: Ar-Ruzz Media
Danu, Eko Agustinova. 2015. Hambatan Pendidikan Karakter di Sekolah Islam Terpadu Studi Kasus SDIT AlHusna Klaten. Jurnal Ilmu Sosial. Vol 12 No 1, 12-1B, (Online),(journal.uny.ac.id/ind ex.php/sosia/article/download/ 5313/4618), dikakses 18 November 2016.

Daryanto. 2013. Implementasi Pendidikan Karakter di sekolah. Yogyakarta: Gava Media

Ida Nurhayati Setiyarini. 2014. Penerapan Sistem Pembelajaran "Fun \& Full Day School" Untuk Meningkatkan Religiuitas Peserta Didik di SDIT AlIslam Kudus.Jurnal Teknologi Pendidikan dan Pembelajaran. Vol 2 No 2, April 2014, (Online),

(http://jurnal.fkip.uns.ac.id/ind ex.php/tp/article/view/3680), diakses 22 November 2016.

Kesuma, Dharma, dkk. 2011. Pendidikan Karakter Kajian Teori dan Praktik di Sekolah. Bandung: PT Remaja Rosda Karya

Lickona Thomas. 2015. Educating For Character. Mendidik untuk Membentuk Karakter.Jakarta: PT Bumi Aksara

Majid, Abdul. 2012. Pendidikan Karakter Perspektif Islam. Bandung: PT Remaja Rosdakarya

Melisa, Oci. 2012. Model Pendidikan Karakter di Islamic Fullday School. Jurnal Tarbawi Vol 1 No 3, September 2012, (Online), (http://jurnal.upi.edu/tarbawi/vi ew/1303/model-pendidikankarakter-di-islamic-full-day- 
school-studi-deskriptif-padasd-cendekia-leadershipschool,-bandung-.html), diakses 8 Desember 2016.

Muhibbin, Syah. 2004. Psikologi Pendidikan dengan Pendidikan Terpadu. Jakarta: CV Rajawali

Muslihin, Al Hafizh. 2013. Pengertian Full Day School. (Online), (http://www.referensimakalah. com/2013/01/pengertian-fullday-school.html), Diakses 5 Desember 2016

Naim, Ngainun. 2012. Character Building. Jogjakarta: Ar-Ruzz Media

Nurani. 2005. Untung Rugi Full Day School. Surabaya: Edisi 221 Surabaya

Samani, Muchlas. 2012. Pendidikan Karakter. Bandung: PT Remaja Rosdakarya

Saptono. 2011. Dimensi-dimensi Pendidikan Karakter. Jakarta: Esensi Erlangga Group

Sehudin . 2005. Pegaruh Pelaksanaan Pembelajaran Full Day School Terhadap Akhlak Peserta SUNAN AMPEL.Surabaya, (Online), (http://jurnal.uinsby.ac.id/1254 3/5/Bab\%202.pdf) diakses 2 Januari 2017

Sisdiknas. 2003. Undang-Undang Republik Indonesia Nomor 20 Tahun 2003 Tentang Sistem Pendidikan Nasional. Jakarta: Depdiknas

Sugiyono. 2011. Metode Penelitian Kuantitatif,Kualitatif dan $R \& D$. Bandung: Alfabeta

Sulistyaningsih, Wiwiik. 2008. Full Day School dan Optimalisasi

$\begin{array}{lr}\text { Perkembangan } & \text { Anak. } \\ \text { Jogjakarta: } & \text { Paradigma } \\ \text { Indonesia } & \end{array}$

Syukur. 2008. Fullday School Harus Proporsional. Jakarta: Pustaka Pelajar.

Taufik, Tuhana.2011. Mengembangkan Karakter Sukses Anak di Era Cyber. Jogjakarta: Ar.Ruzz Media

Didik. Tesis jurusan PAI fakultas tarbiyah IAIN 